\title{
PAGE analysis of the heteroduplexes formed between PCR-amplified 16S rRNA genes: estimation of sequence similarity and rDNA complexity
}

\author{
Romilio T. Espejo, Carmen Gloria Feijóo, Jaime Romero \\ and Mónica Vásquez
}

Instituto de Nutrición y Tecnología de los Alimentos, University of Chile, Macul 5540, Santiago, Chile

\author{
Author for correspondence: Romilio T. Espejo. Tel: +562 6781426. Fax: +5622214030. \\ e-mail: respejo@uec.inta.uchile.cl
}

\begin{abstract}
Analysis of the 165 rRNA genes retrieved directly from different environments has proven to be a powerful tool that has greatly expanded our knowledge of microbial diversity and phylogeny. It is shown here that sequence similarity between 80 and $100 \%$ among 165 rDNAs can be estimated by the electrophoretic migration of their heteroduplexes. This was measured by hybridization and electrophoresis in polyacrylamide gels of the product obtained after PCR amplification of almost the entire 165 rRNA gene from different bacterial species. These heteroduplexes were also observed after amplification of samples containing DNA from two or more bacterial species and a procedure was applied to identify reliably heteroduplexes among the amplification products. The electrophoretic migration of the heteroduplexes observed after PCR was used to detect the presence of 165 rDNAs with different sequences in DNA extracted from both a mixture of two bacterial species and samples containing a natural bacterial community.
\end{abstract}

Keywords: $16 \mathrm{~S}$ rRNA, heteroduplex, phylogeny, diversity

\section{INTRODUCTION}

Our knowledge of microbial diversity has been greatly extended by comparative sequence analysis of genes performed directly on DNA extracted from different environments. This has proven to be a powerful tool for detecting the presence of a high diversity of microorganisms, independent of their ability to grow in culture media (Amann et al., 1995). Because of their universal distribution, high conservation and apparent absence of interspecific transfer, 16S rRNAs genes are commonly analysed (Amann et al., 1995; Lane et al., 1985; Ward et al., 1992; Woese, 1987), usually by cloning and sequencing after PCR amplification. This is labour-intensive and so several other methods for estimation of sequence differences among PCRamplified $16 \mathrm{~S}$ rDNAs have been applied. These include analysis by RFLP patterns (Moyer et al., 1994), denaturing gradient gel electrophoresis (Muyzer et al., 1993) and single-strand conformation polymorphism

Abbreviation: HMA, heteroduplex mobility assay.
(Lee et al., 1996). The heteroduplex mobility assay (HMA) has been shown to be a powerful technique to screen sequence dissimilarity between annealed strands (Delwart et al., 1993), but it has not been extended to the comparison of bacterial $16 \mathrm{~S}$ rDNA sequences.

HMA is based on the annealing of nucleic acid strands that are not fully complementary and therefore produce heteroduplexes with distortions of the double helix in regions where mismatched or unpaired nucleotides occur. The unpaired single-stranded regions form structures of different shapes (Sheffield et al., 1993; Yap \& McGee, 1994), which decrease the electrophoretic mobility of the hybrid. This reduction in mobility has been used to estimate sequence dissimilarity among heteroduplexes formed between amplification products of different genes, and has been applied to the detection of mutations (Mauser et al., 1996; Olds et al., 1993). Though mispairing seldom causes a noticeable reduction in mobility in convential agarose gels, it has a drastic effect in polyacrylamide gels (Delwart et al., 1993), allowing in many cases detection of single base differences (Ganguly et al., 1993; White et al., 1992). 
HMA has recently been applied to distinguish species or genotypes of bacteria (Espejo \& Romero, 1997) and viruses (Bachman, 1997; Chezzi, 1996; Delwart et al., 1993; Kreis, 1997).

Formation of heteroduplexes also occurs during PCR amplification of partially homologous genes and the pattern obtained from a single species enables allelic polymorphism and mutations in heterozygous individuals to be detected (Bowen et al., 1997; White et al., 1992), and has also been applied to the genotyping of different species (Jensen \& Hubner, 1996; Rubocki et al., 1992; Tang et al., 1995, 1996; Zimmerman et al., 1995).

We show here that heteroduplex formation by amplified $16 S$ rDNA provides a rapid and convenient method for assessing the $16 \mathrm{~S}$ rDNA similarity of bacterial isolates and also for detecting bacterial diversity in a natural community.

\section{METHODS}

Bacterial strains. DNA was extracted (see below) from the following strains: Staphylococcus xylosus ATCC 29971, Staphylococcus epidermidis ATCC 14990, Staphylococcus simulans ATCC 27851, Staphylococcus saprophyticus ATCC 15305, Corynebacterium pseudodiphtheriticum ATCC 10700, Corynebacterium pseudotuberculosis ATCC 19410, Aeromonas hydrophila ATCC 7966, Escherichia coli K-12, Pseudomonas stutzeri ATCC 17588, Haemophilus influenzae ATCC 33391, Lactobacillus acidophilus ATCC 4356, Lactobacillus casei ATCC 393, Acinetobacter calcoaceticus ATCC 19606, Clostridium novyi ATCC 19402 and Micrococcus roseus (now Kocuria rosea) ATCC 186.

DNA extraction and amplification. DNA was extracted and purified for amplification as previously described (Espejo \& Romero, 1997). In short, the method comprises lysis of the bacteria with SDS, treatment with ribonuclease $\mathrm{A}$ and proteinase $\mathrm{K}$, subsequent extraction with phenol/chloroform and dialysis against TE buffer (0.01 M Tris, 0.001 M EDTA, $\mathrm{pH} 7 \cdot 5)$. The amount of DNA was estimated visually by comparison of the ethidium-bromide-stained bands with appropriate standards after electrophoresis in $1 \%$ agarose gels. PCR amplification was performed as described by DeLong (1992) with primers Eubac27F and 1492R in a Hybaid Omm-E thermal cycler, with the following modifications: the $\mathrm{pH}$ was $9 \cdot 0$, Triton $\mathrm{X}-100$ was added to a final concentration of $0 \cdot 1 \%(\mathrm{v} / \mathrm{v})$ and the concentration of DNA template was $0 \cdot 1$ ng $\mu l^{-1}$. The different mixtures of DNA from $S$. simulans, $S$. epidermidis, A. hydrophila and L. acidophilus were amplified at a concentration of $0.03 \mathrm{ng} \mu \mathrm{l}^{-1}$ each, whilst DNA extracted from bioleached mineral was added at $0.003 \mathrm{ng} \mu \mathrm{l}^{-1}$. Thermal cycling was as follows: a first cycle at $95^{\circ} \mathrm{C}$ for $3 \mathrm{~min}, 58^{\circ} \mathrm{C}$ for $6 \mathrm{~min}$ and $72^{\circ} \mathrm{C}$ for $1.5 \mathrm{~min}$; a second cycle at $95^{\circ} \mathrm{C}$ for 1.5 $\min , 58^{\circ} \mathrm{C}$ for $3 \mathrm{~min}$ and $72^{\circ} \mathrm{C}$ for $1.5 \mathrm{~min} ; 30$ cycles at $95^{\circ} \mathrm{C}, 58^{\circ} \mathrm{C}$ and $72{ }^{\circ} \mathrm{C}$ for $1.5 \mathrm{~min}$ each; and a final cycle at $95^{\circ} \mathrm{C}$ for $1.5 \mathrm{~min}, 58^{\circ} \mathrm{C}$ for $1.5 \mathrm{~min}$ and $72{ }^{\circ} \mathrm{C}$ for $5 \mathrm{~min}$. When amplification was performed with different numbers of cycles, the decrease was in the 30 cycle component of the above.

Heteroduplex analysis. Denaturation and renaturation of mixed amplified $16 \mathrm{~S}$ rDNA from different bacterial species was performed as follows : pairs of amplified $16 \mathrm{~S}$ rDNAs were

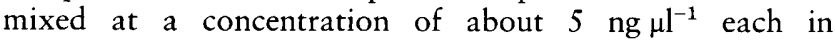

renaturation buffer $[0 \cdot 1 \mathrm{M} \mathrm{NaCl}, 10 \mathrm{mM}$ Tris $/ \mathrm{HCl}(\mathrm{pH} 7 \cdot 8)$, $2 \mathrm{mM}$ EDTA] (Delwart et al., 1993) diluted 1:2 in distilled water, denatured at $98^{\circ} \mathrm{C}$ for $7 \mathrm{~min}$ and subsequently renatured at $60^{\circ} \mathrm{C}$ for $40 \mathrm{~min}$. Denaturation and renaturation of the amplification products from the samples containing more than one DNA species were performed directly in the same buffer and reagents used for the amplification after addition of EDTA to a final concentration of $4 \mathrm{mM}$, at the temperature and times described above. When other conditions were used they are specified in the text. Electrophoresis was performed in either $7 \%$ or $3.5 \%(\mathrm{w} / \mathrm{v})$ polyacrylamide gels ( $7 \mathrm{~cm}$ long $\times 8 \mathrm{~cm}$ wide $\times 0.15 \mathrm{~cm}$ thick) with Tris/borate buffer (Sambrook et al., 1989), at $250 \mathrm{~V}$ for $2.5 \mathrm{~h}$. DNA was visualized by staining with silver nitrate (Espejo \& Escanilla, 1993) and the amount of DNA in each band was calculated after scanning with Molecular Analyst/PC (Bio-Rad), using the volume analysis tool. Sequence similarities among the $16 \mathrm{~S}$ rDNA amplified regions were calculated using sequences obtained from the Ribosomal Data Project (Van de Peer et al., 1994) aligned with the program SSEARCH (Pearson, 1991; Smith \& Waterman, 1981).

\section{RESULTS}

\section{Electrophoretic mobility of 165 rDNA heteroduplexes in polyacrylamide gels and sequence similarity}

To explore the suitability of the HMA method for analysis of $16 \mathrm{~S}$ rDNAs, we first determined the decrease in the mobility of the heteroduplex formed between amplified $16 \mathrm{~S}$ rDNAs with different sequence similarities. Amplified 16S rDNAs from different species were mixed in similar concentrations and then denatured and renatured as described above. Homoduplexes and heteroduplexes were subsequently resolved by electrophoresis in $7 \%$ polyacrylamide gels and the migration of the heteroduplex relative to that of the homoduplex determined. This was roughly proportional to the percentage similarity between the amplified regions of the $16 \mathrm{~S} \mathrm{rDNAs}$ of the bacteria to a level of about $80 \%$ (Fig. 1). Heteroduplexes with similarities below $80 \%$ were usually less conspicuous, probably due to formation in lower amounts because of lower annealing. They were, however, better observed in $3.5 \%$ polyacrylamide gels (Fig. 2). Heteroduplexes were usually resolved into two bands that probably correspond to the hybrids formed by each, plus and minus complementary strands of amplified $16 \mathrm{~S}$ rDNAs. Although the extent of dissimilarity in hybrid pairs is identical, the single-stranded regions in each hybrid may form distinct structural conformations which decrease the mobility to different extents (Jensen \& Straus, 1993). The difference in migration between these hybrids is a good indication of the variability that can be observed among heteroduplexes with the same percentage similarity. The difference in relative migration between these heteroduplex pairs can be as large as $0 \cdot 12$, which according to the approximate relationship shown in Figs 1 and 2 would correspond to a similarity difference of about $2 \%$. These results demonstrate that the determination of the electrophoretic mobility of the heteroduplex formed by the amplified 16S rDNA from an unknown bacterial strain with those from other bacterial 
(a)

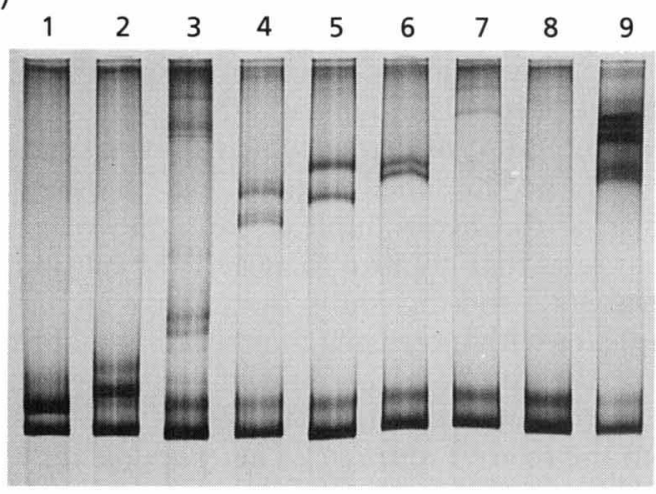

(b)

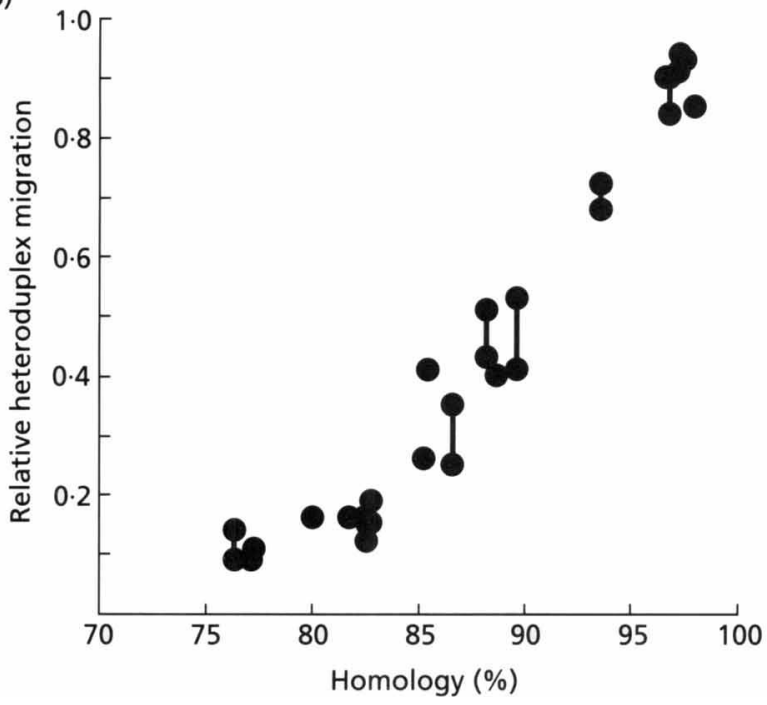

Fig. 1. Electrophoretic migration of heteroduplexes between amplified $16 \mathrm{~S}$ rDNAs with different percentage similarity in $7 \%$ polyacrylamide gels. Amplification products from different bacterial species were mixed, denatured, renatured and subsequently subjected to electrophoresis (see Methods). (a) Lanes 1-7 show the pattern observed with annealed, amplified $16 \mathrm{~S}$ rDNAs from the following bacterial pairs: 1, S. xylosus with S. epidermidis; 2 , S. simulans with $S$. saprophyticus; $3, C$. pseudodiphtheriticum with $C$. pseudotuberculosis; 4, A. hydrophila with $E$. coli; 5, A. hydrophila with P. stutzeri; 6, A. hydrophila with $H$. influenzae; $7, H$. influenzae with $S$. simulans. Lanes 8 and 9 show controls performed with amplified $16 \mathrm{~S}$ rDNAs of $A$. hydrophila and $H$. influenzae (pattern after annealing shown in lane 6); lane 8 shows the pattern obtained when mixing both amplified $16 \mathrm{~S}$ rDNAs after denaturation and renaturation, and lane 9 that obtained after denaturation without renaturation. (b) Relative migration, calculated as the distance of migration of the heteroduplex divided by that of the homoduplex, plotted against percentage sequence homology. Data include those obtained in (a) and in additional experiments. When reciprocal heteroduplexes were resolved, both relative migrations were included in the graph joined by a vertical line.

species is a useful and simple tool to estimate $16 \mathrm{~S} \mathrm{rDNA}$ similarity values larger than $80 \%$. The possible origin of the band observed immediately above the $16 \mathrm{~S}$ rDNA homoduplex is discussed below. (a)

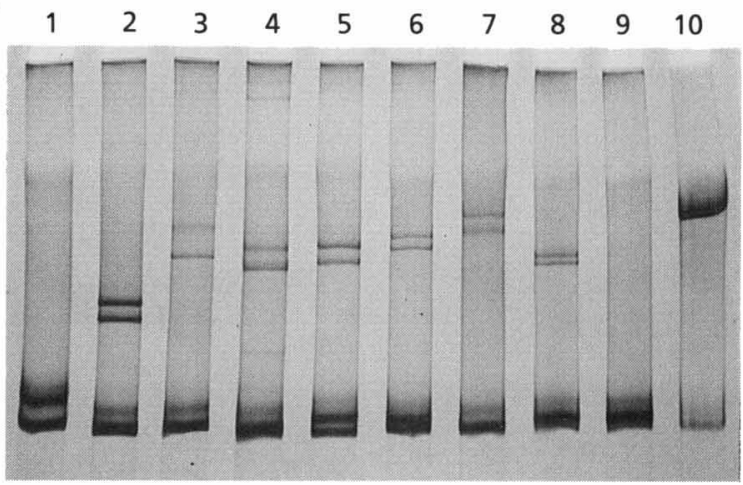

(b)

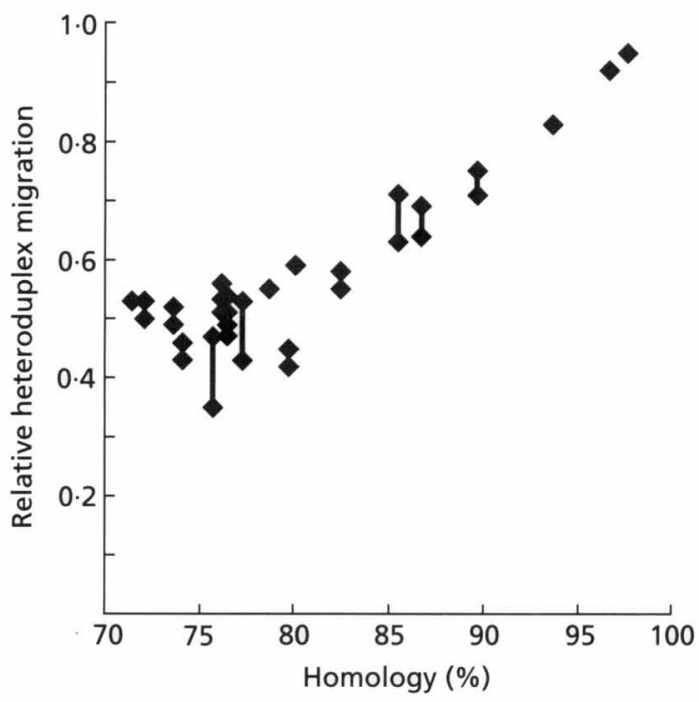

Fig. 2. Electrophoretic migration of heteroduplexes between amplified 165 rDNAs with different percentage similarity in $3.5 \%$ polyacrylamide gels. Amplification products were mixed, denatured, renatured and subsequently subjected to electrophoresis. (a) Lanes 1-8 show the electrophoretic pattern observed with annealed amplified 165 rDNAs from the following bacterial pairs: $1, S$. simulans with S. saprophyticus; 2 , $P$. stutzeri with $A$. hydrophila; $3, S$. simulans with $H$. influenzae; 4, S. saprophyticus with C. pseudotuberculosis; $5, L$. acidophilus with $A$. hydrophila; 6 , L. casei with $A$. calcoaceticus; $7, L$. acidophilus with $H$. influenzae; $8, L$. acidophilus with $E$. coli. Lane 9 shows the pattern obtained when mixing the amplified 165 rDNAs shown in lane 8 but after independent denaturation and renaturation, and lane 10 that obtained with the same sample after denaturation without renaturation. (b) As described in Fig. 1.

\section{Heteroduplex formation during PCR amplification of DNA samples that contain different 165 rDNAs}

Amplification of $16 \mathrm{~S}$ rDNA from DNA samples containing different bacterial species undoubtedly forms heteroduplexes, but their presence is usually undetected as the electrophoresis is performed in agarose gels. The heteroduplexes which develop probably originate from annealing of the single-stranded products between the denaturation and primer annealing steps of the thermal 

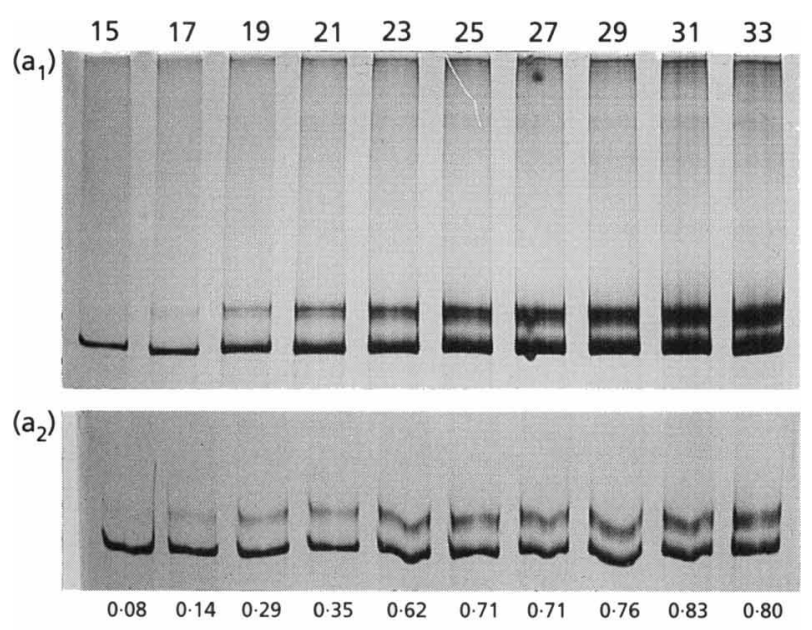

(b)

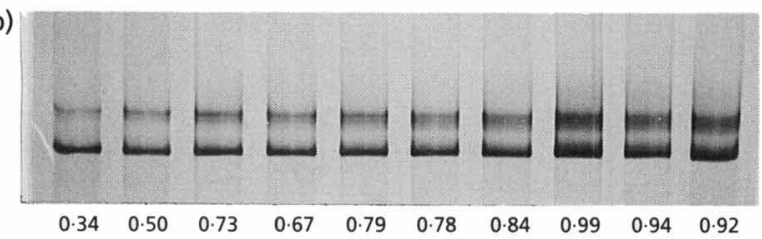

(c)

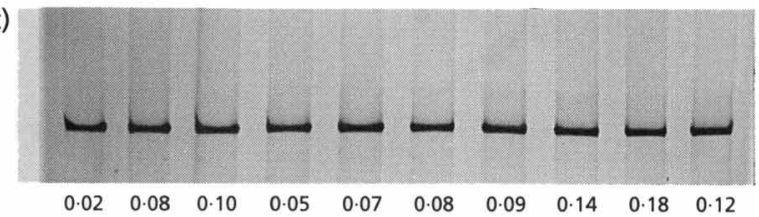

(d)

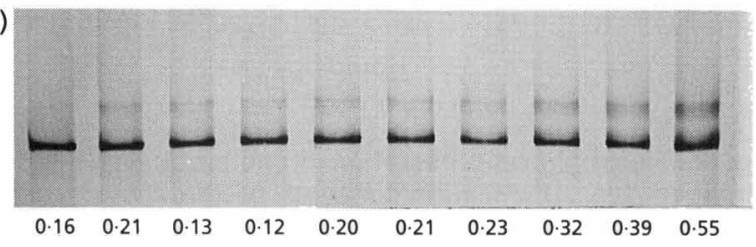

Fig. 3. Analysis of the products obtained after increasing cycles of amplification of a mixture of DNA from $S$. epidermidis and $S$. simulans. The number of cycles is indicated above each lane. $\left(a_{1}\right)$ Products in $1 \mu \mathrm{l}$ amplified mixture; $\left(a_{2}\right)$ products using adjusted volumes of sample from each cycle to allow comparison of similar amounts. The ratios of the amount of heteroduplex relative to the homoduplex are indicated below each lane. Subsequent electrophoresis separations were performed using adjusted sample volumes as in $\left(a_{2}\right)$. (b) Products obtained after denaturation and renaturation of the samples shown in (a). (c) Products obtained after a single amplification cycle of samples in (a), performed after a $1 / 10$ dilution in amplification mixture [five times the volume applied for electrophoresis in $\left(a_{2}\right)$ was used to compensate for the dilution performed, assuming that the product was doubled after the amplification cycle]. (d) Products after denaturation and renaturation of samples shown in (c). Denaturation and renaturation were performed at $95^{\circ} \mathrm{C}$ for $10 \mathrm{~min}$ and $70^{\circ} \mathrm{C}$ for $100 \mathrm{~min}$, respectively, in the same buffer and reagents used for the amplification.

cycle. The suitability of a method based on the appearance of heteroduplexes to assess bacterial diversity was tested with different samples consisting of synthetic mixtures of two, three and four DNAs from different species and with a DNA sample extracted from bioleached copper sulphides. The first sample examined was a mixture of equal amounts of DNA extracted from S. epidermidis and $S$. simulans, which show a similarity of $97.5 \%$ in the amplified region. Fig. 3 shows the appearance of the heteroduplexes and the results of subsequent tests that confirm their actual heteroduplex nature. Fig. $3\left(a_{1}\right)$ and $\left(a_{2}\right)$ show the relative increase of heteroduplexes with increasing number of amplification cycles, probably due to higher annealing because of the increasing product concentration. Fig. $3(\mathrm{~b})$ shows the increase in the relative amount of heteroduplexes when the amplification products were subjected to denaturation and subsequently to renaturation at $70^{\circ} \mathrm{C}$ to avoid primer competition during annealing. Fig. 3(c) shows the resolution of the heteroduplexes into homoduplexes when the products were subjected to an additional amplification cycle after appropriate dilution to avoid their annealing, and Fig. 3(d) shows the recovery of the heteroduplexes from these homoduplexes after denaturation and renaturation.

The second sample examined was a mixture of equal amounts of DNA from three different bacterial species. The discrimination of heteroduplexes in the amplification product of mixtures of DNA from either $A$. bydrophila or L. acidophilus with the above staphylococci is shown in Fig. 4(a) and (b), respectively. Fig. 4(c) shows the heteroduplexes of the mixture of these four DNAs. The similarity between the amplified $16 \mathrm{~S}$ rDNA regions of $A$. hydrophila and $L$. acidophilus with those of the staphylococci is about $77 \%$ and $84 \%$, respectively, while the similarity between $A$. bydrophila and $L$. acidophilus is $76 \%$. As indicated above, heteroduplexes which formed between strands sharing low similarity appeared weaker and were more difficult to distinguish, especially as some bands remained in the upper part of the gel after dilution and a single amplification cycle to resolve the heteroduplexes (lane 2). To avoid primer extension during renaturation at $60{ }^{\circ} \mathrm{C}, 4 \mathrm{mM}$ EDTA was added in these experiments. Fig. 4 also shows the product obtained from a DNA extract from copper sulphides subjected to bioleaching. Analysis of the spacer regions between the $16 \mathrm{~S}$ and $23 \mathrm{~S}$ rRNA genes in this DNA had indicated that the bacteria in the original sample consisted of a community composed of a homogeneous population of Thiobacillus thiooxidans, and populations of Thiobacillus ferrooxidans and 'Leptospirillum ferrooxidans', comprised of at least four and three different strains, respectively (Espejo \& Romero, 1997). Fig. 4(d $\left.d_{1}\right)$ shows the products obtained after annealing at $70^{\circ} \mathrm{C}$ and electrophoresis in $7 \%$ polyacrylamide gel. Under these conditions, only the heteroduplexes expected between different strains of $T$. thiooxidans and T. ferrooxidans, with similarities between 97 and $100 \%$ in 16S rRNA (Goebel \& Stackebrandt, 1994), were observed. Those expected between 'Leptospirillum ferrooxidans' and the thiobacilli, with similarities of about $74 \%$ (Goebel \& Stackebrandt, 1994), could only be observed after 

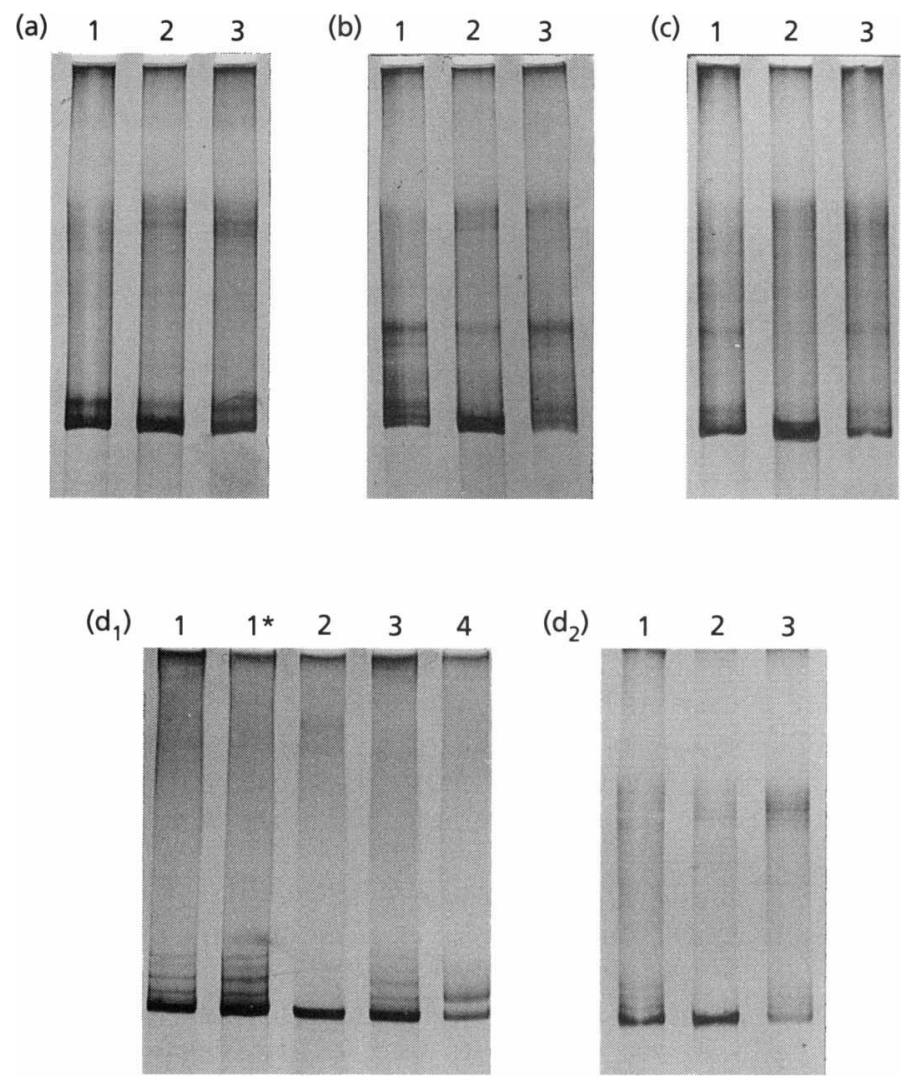

Fig. 4. Analysis of the amplification products obtained from samples containing DNA from different bacterial species. Lanes: 1 , amplification products; 2 , same products subjected to an additional amplification cycle after a $1 / 10$ dilution; 3 , products shown in lane 2 subjected to denaturation and renaturation. Gels show the amplification of a mixture of DNAs from (a) $S$. epidermidis, $S$. simulans and $A$. hydrophila; (b) S. epidermidis, S. simulans and $L$. acidophilus; and (c) S. epidermidis, $S$. simulans, $A$. hydrophila and $L$. acidophilus. Gels shown in $\left(d_{1}\right)$ and $\left(d_{2}\right)$ show the products from DNA extracted from bioleached copper ore. Lane $1^{*}$ shows the products obtained after denaturation and renaturation of those shown in lane 1. Lane 4 shows the heteroduplex formed between amplified 165 rDNA of $T$. ferrooxidans DSM 583 and $T$. thiooxidans ATCC 19377. In $\left(d_{1}\right)$, renaturation was performed at $70^{\circ} \mathrm{C}$ as described in Fig. 3 and the electrophoresis was performed in $7 \%$ polyacrylamide gels. In (a), (b), (c) and $\left(d_{2}\right)$, renaturation was performed at $60^{\circ} \mathrm{C}$ as described in Methods and the electrophoresis in $3.5 \%$ polyacrylamide gels. annealing at $60^{\circ} \mathrm{C}$ and electrophoresis in $3.5 \%$ polyacrylamide gels (Fig. $4 \mathrm{~d}_{2}$ ).

\section{DISCUSSION}

The results presented here demonstrate that $16 \mathrm{~S}$ rDNA sequence similarities between 80 and $100 \%$ can be estimated by the relative electrophoretic migration of the heteroduplexes in polyacrylamide gels. Thus, comparison of the migration of the heteroduplexes formed between amplified 16S rDNA from an unknown bacterium and properly selected bacterial species is potentially a useful taxonomic tool. It can be performed in a short time and requires only nanograms of DNA. Generally, $1 \mu$ l of the amplification product is sufficient for each hybridization and the product can be readily compared with 20 other amplified $16 \mathrm{~S}$ rDNAs in a single day. Its usefulness has been shown by the extensive application of the method developed by Delwart et al. (1993) in the genetic classification of HIV viruses (Bachmann et al., 1994; Novitsky et al., 1996). Heteroduplex formation could be also applied to explore the presence of $16 \mathrm{~S} \mathrm{rDNAs}$ related to any particular species, following a procedure similar to that previously described with 16-23S rDNA spacers (Espejo \& Romero, 1997). In this case labelled amplified 165 rDNA from a particular species, at low concentration to avoid selfannealing, could be hybridized to amplified $16 \mathrm{~S}$ rDNA from the sample. The presence of labelled homoduplex will show the existence of that particular species, while that of heteroduplexes will show the presence of species phylogenetically related according to the migration of the heteroduplexes. Moreover, the results also indicate that heteroduplex formation during PCR amplification of DNA extracted from bacterial communities can be useful for preliminary assessments of the number of $16 \mathrm{~S}$ rDNAs differing in nucleotide sequence in the sample. Interpretation of the results obtained with simple communities containing two species is straightforward. However, interpretation of the heteroduplex pattern from more complex communities, which usually contain four or more different rRNA genes, is difficult because of the large number of potential heteroduplexes. Also, heteroduplexes between $16 \mathrm{~S}$ rDNAs in lower proportion or/and with lower similarity can be undetected. True heteroduplexes could be distinguished from other possible hybridization products because they disappear after dilution and a single cycle of amplification, and reappear after denaturation and renaturation of this product. Interestingly, the band observed immediately above the $16 \mathrm{~S}$ rDNA homoduplex after amplification of DNA from pure cultures behaved as a heteroduplex when examined for these properties. Its presence could be due to sequence polymorphism among the $16 \mathrm{~S} \mathrm{rDNAs}$, even in pure cultures. As recently suggested, microheterogeneity within the rRNA operons of a single species could be a common phenomenon in nature (Nübel et al., 1996; Wang et al., 1997).

Heteroduplexes are probably formed during the tem- 
perature decrease from the denaturation to the annealing step of the amplification cycle. They were observed only after the product reached a concentration of about $10^{-\overline{5}}$ nucleotide-mol $1^{-1}$ (Fig. 3). At this concentration, assuming a half complete renaturation $\left(C_{0} t_{\frac{1}{2}}\right)$ value of 0.003 (nucleotide-mol s) $l^{-1}\left(1400 / 3500\right.$ times the $C_{0} t_{\frac{1}{2}}$ of bacteriophage MS2 DNA) (Marmur et al., 1963; Wetmur \& Davidson, 1968) and that annealing nucleation sites can be formed between 85 and $70{ }^{\circ} \mathrm{C}$, about $20 \%$ of the product would renature during the approximately $60 \mathrm{~s}$ that elapses in our thermal cycler between these two temperatures. The increment in the heteroduplex/homoduplex ratio $(\mathrm{He} / \mathrm{Ho})$ observed with increasing number of thermal cycles (Fig. 3) deserves a detailed discussion. According to the theory of annealing or reassociation kinetics (Britten \& Davidson, 1976; Wetmur \& Davidson, 1968), He/Ho should be a function of the ratio between the relative concentrations of heterologous DNAs and the annealing constants for heteroduplex and homoduplex formation, and should be independent of the total DNA concentration. However, during PCR amplification, homoduplex is formed by both annealing of the singlestranded DNA and primer extension, and in this situation $\mathrm{He} / \mathrm{Ho}$ would be equal to the amount of heteroduplex formed by annealing divided by the amount of homoduplex formed by annealing plus that formed by primer extension. Since annealing and hence heteroduplex formation will increase with product concentration, $\mathrm{He} / \mathrm{Ho}$ should increase with augmenting cycles, as observed. Formation of homoduplex by primer extension would also explain the large decrease in $\mathrm{He} / \mathrm{Ho}$ after denaturation and renaturation of the product that was subjected to dilution and a further single amplification cycle (Fig. $3 \mathrm{~d}_{1}$ ). Since in this case active enzyme and reagents were still available and EDTA was not added, a considerable proportion of the homoduplex could have been formed by primer extension during the $100 \mathrm{~min}$ annealing time, although this was performed at $70^{\circ} \mathrm{C}$. To avoid primer extension during reannealing at $60^{\circ} \mathrm{C}$, EDTA was added to the reaction buffer (Fig. 4). Heteroduplex formation may have serious consequences when denaturing gradient gel electrophoresis is employed to estimate diversity. The heteroduplexes formed during amplification of heterogeneous samples may generate additional bands that would lead to a serious overestimation of diversity. Heteroduplex formation should be considered to explain the bias caused by template annealing in the amplification of mixtures of $16 \mathrm{~S}$ rDNA genes by PCR. This has been observed and studied by Suzuki \& Giovannoni (1996) but they assumed that each template reanneals only to the homologous complement and so does not inhibit the priming reaction of the other template. As shown here, the extent of annealing between heterologous $16 \mathrm{~S}$ rDNAs is large and this would alter the conclusions of the above authors. Further quantitative studies on heteroduplex formation are needed to understand the complex product formation kinetics during PCR amplification of a mixture with partially homologous target regions.

\section{ACKNOWLEDGEMENTS}

We thank Brett M. Goebel for critical review of the manuscript. This work was supported by a grant 1961216 from FONDECYT.

\section{REFERENCES}

Amann, R. I., Ludwig, W. \& Schleifer, K.-H. (1995). Phylogenetic identification and in situ detection of individual microbial cells without cultivation. Microbiol Rev 59, 143-169.

Bachmann, M. H. (1997). Genetic diversity of feline immunodeficiency virus: dual infection, recombination, and distinct evolutionary rates among envelope sequence clades. $J$ Virol 71, 4241-4253.

Bachmann, M. H., Delwart, E. L., Shpaer, E. G., Lingenfelter, P., Singal, R. \& Mullins, J. I. (1994). Rapid genetic characterisation of HIV type 1 strains from four World Health Organisationsponsored vaccine evaluation sites using a heteroduplex mobility assay. AIDS Res Hum Retrovir 10, 1345-1353.

Bowen, D. J., Standen, G. R., Granville, S., Bowley, S., Wood, N. A. \& Bidwell, J. (1997). Genetic diagnosis of factor V Leiden using heteroduplex technology. Thromb Haemostasis 77. 119-122.

Britten, R. J. \& Davidson, E. H. (1976). Studies on nucleic acid reassociation kinetics: empirical equations describing DNA reassociation. Proc Natl Acad Sci USA 73, 415-419.

Chezzi, C. (1996). Differentiation between vaccine-related and wild-type polioviruses using a heteroduplex mobility assay. J Virol Methods 62, 93-102.

DeLong, E. F. (1992). Archaea in coastal marine environments. Proc Natl Acad Sci USA 89, 5685-5689.

Delwart, E. L., Shpaer, E. G., Louwagie, J., McCutcham, F. E., Grez, M., Rübsamen-Waigmann, H. \& Mullins, J. I. (1993). Genetic relationships determined by a DNA heteroduplex mobility assay: analysis of HIV-1 env genes. Science 262, 1257-1261.

Espejo, R. T. \& Escanilla, D. (1993). Detection of HIV1 DNA by a simple procedure of polymerase chain reaction, using 'primerdimer' formation as an internal control of amplification. Res Virol 144, 243-246.

Espejo, R. T. \& Romero, J. (1997). Bacterial community in copper sulfide ores inoculated and leached with solution from a commercial-scale copper leaching plant. Appl Environ Microbiol 63, 1344-1348.

Ganguly, A., Rock, M. J. \& Prockop, D. J. (1993). Conformationsensitive gel electrophoresis for rapid detection of single-base differences in double-stranded PCR products and DNA fragments: evidence for solvent-induced bends in DNA heteroduplexes. Proc Natl Acad Sci USA 90, 10325-10329.

Goebel, B. M. \& Stackebrandt, E. (1994). Cultural and phylogenetic analysis of mixed microbial populations found in natural and commercial bioleaching environments. Appl Environ Microbiol 60, 1614-1621.

Jensen, M. A. \& Hubner, R. J. (1996). Use of homoduplex ribosomal DNA spacer amplification products and heteroduplex cross-hybridization products in the identification of Salmonella serovars. Appl Environ Microbiol 62, 2741-2746.

Jensen, M. A. \& Straus, N. (1993). Effect of PCR conditions on the formation of heteroduplex and single-stranded DNA products in the amplification of bacterial ribosomal DNA spacer regions. PCR Methods Appl 3, 186-194.

Kreis, S. (1997). Rapid identification of measles virus strains by the heteroduplex mobility assay. Virus Res 47, 197-203. 
Lane, D. L., Pace, B., Olsen, G. J., Stahl, D. A., Sogin, M. L. \& Pace, N. R. (1985). Rapid determination of $16 \mathrm{~S}$ ribosomal RNA sequences for phylogenetic analyses. Proc Natl Acad Sci USA 82 , 6955-6959.

Lee, D.-H., Zo, Y.-G. \& Kim, S.-J. (1996). Nonradioactive method to study genetic profiles of natural bacterial communities by PCRsingle-strand-conformation polymorphism. Appl Environ Microbiol 62, 3112-3120.

Marmur, J., Rownd, R. \& Schildkraut, C. L. (1963). Denaturation and renaturation of deoxyribonucleic acid. In Progress in Nucleic Acid Research, pp. 232-300. Edited by J. N. Davidson \& W. E. Cohn. New York: Academic Press.

Mauser, A. E., Whitlark, J., Whitney, K. M. \& Lothrop, C. D., Jr (1996). A deletion mutation causes hemophilia B in Lhasa dogs. Blood 88, 3451-3455.

Moyer, C. L., Dobbs, F. C. \& Karl, D. M. (1994). Estimation of diversity and community structure through restriction fragment length polymorphism distribution analysis of bacterial $16 \mathrm{~S}$ rRNA genes from a microbial mat at an active, hydrothermal vent system, Loihi seamount, Hawaii. Appl Environ Microbiol 60, 871-879.

Muyzer, G., De Waal, E. C. \& Uitterlinden, A. G. (1993). Profiling of complex microbial populations by denaturing gradient gel electrophoresis analysis of polymerase chain reaction-amplified genes coding for 16S rRNA. Appl Environ Microbiol 59, 695-700.

Novitsky, V., Arnold, C. \& Clewley, J. P. (1996). Heteroduplex mobility assay for subtyping HIV-1: improved methodology and comparison with phylogenetic analysis of sequence data. $J$ Virol Methods 59, 61-72.

Nübel, U., Engelen, B., Felske, A., Snaidr, J., Wieshuber, A., Amann, R. I., Ludwig, W. \& Backhaus, H. (1996). Sequence heterogeneities of genes encoding $16 \mathrm{~S}$ rRNAs in Paenibacillus polymyxa detected by temperature gradient gel electrophoresis. J Bacteriol 178, 5636-5643.

Olds, R., Lane, D., Beresford, C. H., Abilgaard, U., Hughes, P. \& Thein, S. (1993). A recurrent deletion in the antithrombin gene, AT106-108 (-6bp), identified by DNA heteroduplex detection. Genomics 16, 298-322.

Pearson, W. R. (1991). Searching protein sequence libraries: comparison of the sensitivity and selectivity of the SmithWaterman and FASTA algorithms. Genomics 11, 635-650.

Rubocki, R. J., Wisecarver, J. L., Hook, D. D., Cox, S. M. \& Beisel, K. W. (1992). Histocompatibility screening by molecular techniques: use of polymerase chain reaction products and heteroduplex formation. J Clin Lab Anal 6, 337-341.

Sambrook, J., Fritsch, E. F. \& Maniatis, T. (1989). Molecular Cloning: a Laboratory Manual, 2nd edn. Cold Spring Harbor, NY: Cold Spring Harbor Laboratory.
Sheffield, V. C., Beck, J. S., Kwiteck, A. F., Sandstrom, D. W. \& Stone, E. M. (1993). The sensitivity of single-strand conformation polymorphism analysis for the detection of single base substitutions. Genomics 16, 325-332.

Smith, T. F. \& Waterman, M. S. (1981). Identification of common molecular subsequences. J Mol Biol 147, 195-197.

Suzuki, M. T. \& Giovannoni, S. J. (1996). Bias caused by template annealing in the amplification of mixtures of $16 \mathrm{~S}$ rRNA genes by PCR. Appl Environ Microbiol 62, 625-630.

Tang, J., Toe, L., Back, C. \& Unnasch, T. R. (1995). Mitochondrial alleles of Simulium damnosum sensu lato infected with Onchocerca volvulus. Int J Parasitol 25, 1251-1254.

Tang, J., Pruess, K., Cupp, E.W. \& Unnasch, T. R. (1996). Molecular phylogeny and typing of blackflies (Diptera: Simuliidae) that serve as vectors of human or bovine onchocerciasis. Med Vet Entomol 10, 228-234.

Van de Peer, Y., Van den Broeck, I., De Rijk, P. \& De Wachter, R. (1994). Database on the structure of small ribosomal subunit RNA. Nucleic Acids Res 22, 3488-3494.

Wang, Y., Zhang, Z. \& Ramanan, N. (1997). The actinomycete Thermobispora bispora contains two distinct types of transcriptionally active $16 S$ rRNA genes. J Bacteriol 179, 3270-3276.

Ward, D. M., Bateson, M. M., Weller, R. \& Ruff-Roberts, A. L. (1992). Ribosomal RNA analysis of microorganisms as they occur in nature. In Advances in Microbial Ecology, pp. 219-286. Edited by K. C. Marshall. New York: Plenum.

Wetmur, J. G. \& Davidson, N. (1968). Kinetics of renaturation of DNA. J Mol Biol 31, 349-370.

White, M. B., Carvalho, M., Derse, D., O’Brien, S. J. \& Dean, M. (1992). Detecting single base substitutions as heteroduplex polymorphisms. Genomics 12, 301-306.

Woese, C. R. (1987). Bacterial evolution. Microbiol Rev 51, 221-271.

Yap, E. P. H. \& McGee, J. O. (1994). Nonisotopic single strand conformation polymorphism (SSCP) analysis of PCR products. In PCR Technology: Current Innovations, pp. 165-177. Edited by H. G. Griffin \& A. M. Griffin. Boca Raton, FL: CRC Press.

Zimmerman, P. A., Phadke, P. M., Lee, A., Elson, L. H., Aruajo, E., Guderian, R. \& Nutman, T. B. (1995). Migration of a novel DQA1* allele (DQA1*0502) from African origin to North and South America. Hum Immunol 42, 233-240.

Received 30 October 1997; revised 2 February 1998; accepted 4 March 1998. 